\title{
In vivo Quantification of Glial Activation in Minipigs Overexpressing human synuclein
}

DOI:

10.1002/syn.22060

\section{Document Version}

Accepted author manuscript

Link to publication record in Manchester Research Explorer

\section{Citation for published version (APA):}

Lillethorup, T., Nørgaard Glud, A., Landeck, N., Olsen Alstrup, A. K., Jakobsen, S., Vang, K., Doudet, D. J., Kirik, D., Hinz, R., Sørensen, J. C., \& Landau, A. M. (2018). In vivo Quantification of Glial Activation in Minipigs Overexpressing human synuclein. Synapse, 72(12), [e22060]. https://doi.org/10.1002/syn.22060

\section{Published in:}

Synapse

\section{Citing this paper}

Please note that where the full-text provided on Manchester Research Explorer is the Author Accepted Manuscript or Proof version this may differ from the final Published version. If citing, it is advised that you check and use the publisher's definitive version.

\section{General rights}

Copyright and moral rights for the publications made accessible in the Research Explorer are retained by the authors and/or other copyright owners and it is a condition of accessing publications that users recognise and abide by the legal requirements associated with these rights.

\section{Takedown policy}

If you believe that this document breaches copyright please refer to the University of Manchester's Takedown Procedures [http://man.ac.uk/04Y6Bo] or contact uml.scholarlycommunications@manchester.ac.uk providing relevant details, so we can investigate your claim.

\section{OPEN ACCESS}


MISS THEA PINHOLT LILLETHORUP (Orcid ID : 0000-0003-1692-5975)

DR. ANNE M LANDAU (Orcid ID : 0000-0002-7371-8713)

Article type : Research Article

\section{In vivo Quantification of Glial Activation in Minipigs Overexpressing human $\alpha$-synuclein}

Thea Pinholt Lillethorup ${ }^{\dagger}, 1,{ }^{*}$, Andreas Nørgaard Glud ${ }^{\dagger}, 2$, Natalie Landeck ${ }^{3}$, Aage Kristian Olsen Alstrup ${ }^{1}$, Steen Jakobsen ${ }^{1}$, Kim Vang $^{1}$, Doris J Doudet ${ }^{1,4}$, David J Brooks ${ }^{1,5,6}$, Deniz Kirik ${ }^{3}$, Rainer Hinz ${ }^{7}$, Jens Christian Sørensen ${ }^{2}$, Anne M Landau ${ }^{1,8}$

† These authors contributed equally to this work

${ }^{1}$ Department of Nuclear Medicine and PET Center, Aarhus University and Hospital, Denmark (DK)

${ }^{2}$ Center for Experimental Neuroscience (CENSE), Department of Neurosurgery, Aarhus University, DK

${ }^{3}$ Brain Repair and Imaging in Neural Systems (BRAINS) Unit, Department of Experimental Medical Science, Lund University, Sweden

${ }^{4}$ Department of Medicine/Neurology, University of British Columbia, Vancouver, BC, Canada

${ }^{5}$ Division of Neuroscience, Department of Medicine, Imperial College London, UK

${ }^{6}$ Division of Neuroscience, Newcastle University, UK

${ }^{7}$ Wolfson Molecular Imaging Centre, University of Manchester, UK

${ }^{8}$ Translational Neuropsychiatry Unit, Institute of Clinical Medicine, Aarhus University, DK

*Correspondence and requests for materials should be addressed to Anne M Landau (alandau@clin.au.dk), This article has been accepted for publication and undergone full peer review but has not been through the copyediting, typesetting, pagination and proofreading process, which may lead to differences between this version and the Version of Record. Please cite this article as doi: $10.1002 /$ syn. 22060

This article is protected by copyright. All rights reserved. 
Department of Nuclear Medicine and PET Center, Aarhus University, Nørrebrogade 44, Building 10G, $6^{\text {th }}$ floor, Aarhus C, Denmark

\section{Acknowledgements}

We would like to thank the staff at the Aarhus University Hospital PET Centre for their technical assistance and the Aarhus University Farm for their flexibility and help with taking care of the animals. A special appreciation goes to the CENSE group at the Department of Neurosurgery and the Danish Neuroscience Center including Trine Werenberg Mikkelsen, Lise Moberg Fitting and Anne Sofie Møller Andersen. We are grateful to PMOD for providing a free license to the software as part of the MultiSyn collaboration and to Marina Romero-Ramos for insightful comments on this manuscript.

This study was financially supported by the Lundbeck Foundation (grant number 2013-16034) to AML, a grant from the Bjarne Saxhof Fund administered through the Danish Parkinson's Foundation to AML and an European Union's Seventh Framework Programme grant (FP7, 603646, Multisyn). RH has received funding from the EU FP7 (2007-2013) under grant agreement number HEALTH-F2-2011-278850 (INMiND).

\section{Conflict of interest}

The authors have no conflict of interest to declare.

This article is protected by copyright. All rights reserved. 


\section{Abstract}

Parkinson's disease is characterized by a progressive loss of substantia nigra (SN) dopaminergic neurons and the formation of Lewy bodies containing accumulated alpha-synuclein ( $\alpha$-syn). The pathology of Parkinson's disease is associated with neuroinflammatory microglial activation, which may contribute to the ongoing neurodegeneration. This study investigates the in vivo microglial and dopaminergic response to overexpression of $\alpha$-syn. We used positron emission tomography (PET) and the $18 \mathrm{kDa}$ translocator protein radioligand, $\left[{ }^{11} \mathrm{C}\right](\mathrm{R}) \mathrm{PK} 11195$, to image brain microglial activation and $(+)-\alpha-$ $\left[{ }^{11} \mathrm{C}\right]$ dihydrotetrabenazine $\left(\left[{ }^{11} \mathrm{C}\right] \mathrm{DTBZ}\right)$, to measure vesicular monoamine transporter 2 (VMAT2) availability in Göttingen minipigs following injection with recombinant adeno-associated virus (rAAV) vectors expressing either mutant A53T $\alpha$-syn or Green Fluorescent Protein (GFP) into the SN (4 rAAV- $\alpha$-syn, 4 rAAV-GFP, 5 non-injected control minipigs). We performed motor symptom assessment and immunohistochemical examination of tyrosine hydroxylase $(\mathrm{TH})$ and transgene expression. Expression of GFP and $\alpha$-syn was observed at the SN injection site and in the striatum. We observed no motor symptoms or changes in striatal $\left[{ }^{11} \mathrm{C}\right] \mathrm{DTBZ}$ binding potential in vivo or striatal or SN TH staining in vitro between the groups. The mean $\left[{ }^{11} \mathrm{C}\right](\mathrm{R}) \mathrm{PK} 11195$ total volume of distribution was significantly higher in the basal ganglia and cortical areas of the $\alpha$-syn group than the control animals. We conclude that mutant $\alpha$-syn expression in the SN resulted in microglial activation in multiple sub- and cortical regions, while it did not affect TH stains or VMAT2 availability. Our data suggest that microglial activation constitutes an early response to accumulation of $\alpha$-syn in the absence of dopamine neuron degeneration.

\section{Keywords}

Alpha-synuclein, $\left[{ }^{11} \mathrm{C}\right](\mathrm{R}) \mathrm{PK} 11195$, Inflammation, Parkinson's disease, Minipig, animal model, adenoassociated viral vectors

This article is protected by copyright. All rights reserved. 


\section{Introduction}

Aberrant alpha-synuclein ( $\alpha$-syn) aggregation to form Lewy bodies and neurites in association with degeneration of dopaminergic neurons in the substantia nigra (SN) is the defining pathology of Parkinson's disease (PD). This neuronal degeneration is accompanied by intrinsic inflammation in the form of microglial activation and proliferation that leads to expression of various proteins, including the $18 \mathrm{kDA}$ translocator protein (TSPO) (McGeer et al. 1988; Venneti et al. 2006). There is increasing evidence that this neuroinflammation drives disease progression (Bartels \& Leenders 2007; Orr et al. 2002).

Brain microglial activation can be imaged with the TSPO positron emission tomography (PET) radioligand, $\left[{ }^{11} \mathrm{C}\right](\mathrm{R}) \mathrm{PK} 11195$ (Banati 2002). TSPO is a transporter of cholesterol and anions which is expressed by the outer mitochondrial membrane of activated microglia (Papadopoulos et al. 2006). While TSPO shows low expression under normal conditions, any injury to the brain, such as trauma, stroke, and neurodegenerative disorders, increases its expression and its isoquinoline binding sites available for $\left[{ }^{11} \mathrm{C}\right](\mathrm{R}) \mathrm{PK} 11195$ rise (Bonsack et al. 2016; Cagnin et al. 2001; Ouchi et al. 2005). $\left[{ }^{11} \mathrm{C}\right](\mathrm{R}) \mathrm{PK} 11195$ PET has detected brainstem, basal ganglia, and association cortex inflammation in cases of established PD (Gerhard et al. 2006; Ouchi et al. 2005) supported by post-mortem studies detecting reactive microglia using HLA-DR immunohistochemistry (McGeer et al. 1988). Furthermore, increased neuroinflammation has been detected in the monkey with HLA-DR and minipig with $\left[{ }^{11} \mathrm{C}\right](\mathrm{R})$ PK11195 PET following 1-Methyl-4-phenyl1,2,5,6-tetrahydropyridine (MPTP) administration (Cumming et al. 2006; McGeer et al. 2003). While the dopamine depletion in MPTP intoxicated minipigs was restored following grafting, the study observed a significant elevation of $\left[{ }^{11} \mathrm{C}\right](\mathrm{R}) \mathrm{PK} 11195$ volume of distribution $\left(V_{T}\right)$ in the striatum of the grafted pigs (Cumming et al. 2001).

This article is protected by copyright. All rights reserved. 
In our study, mutant $\alpha$-syn was overexpressed in the substantia nigra (SN) of the minipig brain to generate a large animal model with PD pathology. This $\alpha$-syn overexpression approach extends similar studies in mice, rats and marmosets where recombinant adeno-associated viral (rAAV) vectors encoding wild-type or mutant human $\alpha$-syn genes were inoculated into nigral dopamine neurons (Kirik et al. 2003; Maingay et al. 2005; Phan et al. 2017; Ulusoy et al. 2010). These transduction studies led to abnormal accumulation and aggregation of $\alpha$-syn associated with loss of dopaminergic function, axonal pathology and progressive neurodegeneration of tyrosine hydroxylase (TH)-positive neurons in the SN (Kirik et al. 2003; Kirik et al. 2002; van der Putten et al. 2000). Furthermore, early and persistent activation of microglia has previously been reported in AAV-mediated $\alpha$-syn overexpression models in both rodents and primates (Barkholt et al. 2012; Chung et al. 2009; Sanchez-Guajardo et al. 2010).

For the first time, we translate the rodent transfection model to the Göttingen minipig, which presents a superior model for human brain due to the large gyrencephalic porcine brain. Its size (69 g at 12 months) allows for good quantification of magnetic resonance imaging (MRI) and PET markers using commercial/clinical scanners (Bjarkam et al. 2017a; Lind et al. 2007). Here we investigate the distribution of activated microglia and the dopamine terminal integrity in response to nigral inoculation of rAAV vector overexpressing mutant $\alpha$-syn in minipig brain using $\left[{ }^{11} \mathrm{C}\right](\mathrm{R}) \mathrm{PK} 11195$ and $\left[{ }^{11} \mathrm{C}\right] \mathrm{DTBZ}$ PET, respectively.

This article is protected by copyright. All rights reserved. 


\section{Materials and Methods}

\section{Animals}

The Danish Animal Experiments Inspectorate approved this study (2013-15-2934-00820) and we followed the 2010/63/EU directive for protection of animals used for scientific purpose. Thirteen adult female Göttingen minipigs (10.6 \pm 0.8 months; control $n=5$; GFP $n=4 ; \alpha$-syn $n=4)$ from Ellegaard Minipigs ApS (Dalmose, Denmark) were housed in pairs in adjacent pens $\left(4.6 \mathrm{~m}^{2}\right)$ at the Aarhus University animal farm with $50-55 \%$ humidity, $20^{\circ} \mathrm{C}$ air ventilation and with a day/night cycle of $12 \mathrm{~h}$. They were fed a restricted diet with free access to tap water and were weighed every second week. Prior to surgery, the minipigs had acclimatized for at least one month and they were fasted for $16 \mathrm{~h}$ before either PET or surgery.

\section{rAAV vector design and production}

Recombinant AAV vectors contained a cytomegalovirus enhancer element/chicken beta-actin promoter (CBA) and either a human A53T $\alpha$-syn or green-fluorescent protein (GFP) gene followed by an h-SV40 polyA sequence. These cassettes were flanked by inverted terminal repeats (ITR2) and packaged using rAAV serotype 5 capsids.

HEK293 cells at 70-80\% confluence were transfected using the calcium-phosphate precipitation method including the rAAV plasmid and helper plasmids encoding for essential adenoviral packaging and rAAV5 capsid genes as previously described (Grimm et al. 1998). After 3 days of incubation, cells were harvested and lysed by performing three freeze-thaw cycles in a dry ice/ethanol bath. After treatment with benzonase (Sigma, Stockholm, Sweden) the lysate was purified using a discontinuous iodixanol gradient followed by Separose Q column chromatography (Zolotukhin et al. 1999) and then concentrated with a 100

This article is protected by copyright. All rights reserved. 
kD cut-off column (Millipore Amicon Ultra, Millipore, Solna, Sweden). To determine the titer of the viral stock solutions, quantitative PCR with primers and probes targeting the ITR sequence was performed. Stock titers were $4.16 \cdot 10^{14}$ and $6.6 \cdot 10^{14}$ genome copies/mL for $\alpha$-syn and GFP vectors, respectively. Prior to use in experiments, vectors were diluted in phosphate buffered saline. All diluted batches were re-titered and values obtained ranged from $1.04 \cdot 10^{14}$ to $1.16 \cdot 10^{14}$ genome copies $/ \mathrm{mL}$.

\section{Stereotaxic surgery}

Animals were pre-medicated with $6 \mathrm{mg} / \mathrm{kg}$ S-Ketamine (Pfizer) and $1.3 \mathrm{mg} / \mathrm{kg}$ Midazolam (Hameln) IM, intubated and connected to a ventilator. Anesthesia was induced and maintained using $10 \mathrm{mg} / \mathrm{kg} / \mathrm{hr}$ propofol IV (B. Braun) during the whole procedure. Bupivacaine hydrochloride (Marcain ${ }^{\circledR}, 0.5 \%, 0.8 \mathrm{mg} / \mathrm{kg}$, AstraZeneca) was locally injected on the periosteum at the site of surgical incision and at the MR localizer box fixation points. The stereotaxic localizer box (Mark 2.5, Neurologic, Denmark) was fixed to the animal's head and through a scalp incision an MRI-visible fiducial marker was placed in a skull drill hole at bregma, as described previously (Glud et al. 2017; Glud et al. 2011). Animals underwent a 3D T1 MPRAGE MRI scan (3T Trio, Siemens) to permit the calculation of injection coordinates $(1 \times 1 \times 1 \mathrm{~mm}$ reconstruction) in the SN relative to the localizer box and the fiducial marker. Anesthetized animals were transported to a Class II virus facility and a stereotaxic frame was attached to the localizer box. After the scalp incision was reopened, a hole was drilled in the skull using a Midas Rex high-speed drill. When the brain was exposed a small incision was made in the dura. Using a Hamilton syringe (VWR), $20 \mu \mathrm{L}$ of rAAV- $\alpha$-syn $(n=4)$ or rAAVGFP $(n=4)$ was injected into the right SN guided by the calculated injection coordinates over 20 minutes (1 $\mu \mathrm{L} / \mathrm{min}$ ). The assembly was left in place for an extra 5 minutes before being slowly withdrawn. The scalp incision was closed with 2.0 resorbable sutures. After the surgery, minipigs were placed in a quarantine facility for genetically modified animals for $72 \mathrm{~h}$. Animals received pre- and postoperative antibiotics and analgesics including buprenorphine $\left(\right.$ Temgesic $\left.^{\circledR}, 0.01 \mathrm{mg} / \mathrm{kg} \mathrm{IM}\right) 3$ times on the surgery day with 8 hour

This article is protected by copyright. All rights reserved. 
intervals and benzylpenicillin procain (Penovet ${ }^{\circledR}, 15.000 \mathrm{IE} / \mathrm{kg} \mathrm{IM}$ ) and Flunixin ( $2 \mathrm{mg} / \mathrm{kg}$ oral) for 5 days. One GFP-injected animal sustained an infection following the surgical intervention and was excluded from the study.

\section{Analysis of behaviour}

The minipigs were filmed individually from above in an enclosed cage for $30 \mathrm{~min}$ at the same time of the day on separate days at baseline including naïve control minipigs $(n=9)$, at 4 months (GFP $n=4 ; \alpha$-syn $n=$ 4) and 6 months (GFP $n=2 ; \alpha$-syn $n=2$ ) after the injection of AAV- $\alpha$-syn or AAV-GFP vectors. Motor function was assessed blinded using EthoVision XT software (Noldus) by tracking their color-labeled back and measuring the distance moved in the cage during the $30 \mathrm{~min}$ filming.

\section{PET data acquisition and analysis}

Four months after the stereotaxic inoculation of rAAV vectors into the right SN, minipigs were imaged with PET along with 5 naïve controls. The minipigs were pre-medicated and the anesthesia induced using a mixture of midazolam $(1.3 \mathrm{mg} / \mathrm{kg}$ ) and ketamine $(6.0 \mathrm{mg} / \mathrm{kg})$. Animals were intubated and mechanically ventilated while anesthesia was maintained ( $2.1 \%$ Isofluran, Zoetis). Catheters were placed in the femoral artery for arterial blood sampling during the $\left[{ }^{11} \mathrm{C}\right](\mathrm{R}) \mathrm{PK} 11195$ scan and in the ear vein for radiotracer injection (Ettrup et al. 2011). Prior to PET, CT scans were performed for attenuation correction of PET emission data.

A 90 min PET scan was performed in each minipig using a human Biograph64 Truepoint PET-CT scanner

(Siemens Healthcare). Radiotracer injection was administered through the ear vein catheter and flushed

This article is protected by copyright. All rights reserved. 
with $10 \mathrm{~mL}$ saline. The average injected dose and specific activity were $352 \pm 17 \mathrm{MBq}$ and $43 \pm 47 \mathrm{GBq} / \mu \mathrm{mol}$ for $\left[{ }^{11} \mathrm{C}\right](\mathrm{R}) \mathrm{PK} 11195$ and $405 \pm 27 \mathrm{MBq}$ and $212 \pm 201 \mathrm{GBq} / \mu \mathrm{mol}$ for $\left[{ }^{11} \mathrm{C}\right] \mathrm{DTBZ}$. PET data was acquired as 14 time frames $(5 \times 60,3 \times 300,4 \times 600$ and $2 \times 900$ seconds) and images were reconstructed with PSF resolution modelling (TrueX, 3 iterations, 21 subsets) and $2 \mathrm{~mm}$ Gaussian filtering using a 3D algorithm. In some of the animals, varying amounts of activity in the ear vein catheter and tube were observed on the PET images within the field of view. One $\left[{ }^{11} \mathrm{C}\right](\mathrm{R}) \mathrm{PK} 11195$ scan (GFP-injected animal) was excluded based on streak artifacts most pronounced in the initial time frame images most likely caused by a scatter correction error (Alstrup et al. 2018). However, blood information from this animal was used in construction of the standard blood curve.

Blood samples were manually drawn during the $\left[{ }^{11} \mathrm{C}\right](\mathrm{R}) \mathrm{PK} 11195$ scan from the femoral artery $(12 \times 5,6 \times$ $10,6 \times 30,5 \times 60,8 \times 600$ seconds). Blood samples were centrifuged and the plasma radioactivity was measured using a well counter (Cobra II; Packard Instrument Co.) cross-calibrated to the scanner. Plasma data were linearly interpolated. The fraction of radiolabeled parent compound was measured by radioHPLC in plasma samples taken at 2, 5, 10, 20, 30 and 60 min. The HPLC conditions were Spherisorb ODS C18 (Phenomenex, $250 \times 4.6 \mathrm{~mm}$ ) using $80 \%$ methanol and $20 \%$ ammonium formate $0.1 \mathrm{M}$ as fluent, with serial UV $(\lambda=254 \mathrm{~nm})$ and radio detection. Due to problems with femoral artery cannulation, blood samples were drawn from 10 out of the 13 minipigs during the $\left[{ }^{11} \mathrm{C}\right](\mathrm{R}) \mathrm{PK} 11195$ PET scans. Plasma parent radiotracer fractions were obtained for 9 minipigs and these curves were averaged and fitted to a sigmoid model (Guo et al. 2013). Metabolite fractions were not affected by rAAV injection as can be appreciated from the overlapping standard deviations (Figure 1).

Reconstructed images were processed using PMOD 3.6 software (PMOD Technologies Ltd., Zurich, Switzerland). PET images were spatially transformed to an average MRI template based on 22 Göttingen

This article is protected by copyright. All rights reserved. 
minipig brains (Watanabe et al. 2001) using a rigid transformation. Time-activity curves (TACs) for VM (ventral midbrain), STR (striatum), THA (thalamus), pons, FC (frontal cortex), TC (temporal cortex), Cer (cerebellum) and $\mathrm{WhBr}$ (whole brain) were generated based on volumes of interest from a Göttingen minipig PET atlas (Watanabe et al. 2001).

\section{Quantification of $\left[{ }^{11} \mathrm{C}\right](\mathrm{R}) \mathrm{PK} 11195$ binding}

The dynamic PET brain TACs were kinetically analysed using a reversible 1-tissue compartmental model (Gunn et al. 2001). Due to the incomplete blood dataset, a population based plasma input function (PBIF) was derived from the existing datasets, corrected for injected dose, weight and metabolites (Shiozaki et al. 2000). Final fits were performed for a 60 min dataset and $v B$ was kept as a free model parameter, as this provided the most optimal goodness-of-fit assessed by the residual mean squared error, Akaike Information Criterion, and the coefficient of variation. As part of the validation, data was also investigated using a simplified reference tissue model and SUV ratio with cerebellum as reference, which provided similar group binding trends. However, due to uncertainty if cerebellum would represent a valid, nondisplaceable binding region, the 1-tissue compartment model with blood input was preferred. Parametric maps were calculated from 2 mm Gaussian smoothed PET images using a 1-tissue compartment model.

\section{Quantification of $\left[{ }^{11} \mathrm{C}\right] \mathrm{DTBZ}$ binding}

The $\left[{ }^{11}\right.$ C]DTBZ TACs were obtained in left and right striatal and cerebellar regions and the binding potential of specific compared to non-displaceable binding $\left(B P_{N D}\right)$ was computed using Logan graphical analysis (Logan et al. 1996) with the cerebellum providing a reference tissue input and setting t* to 20 min to define the linear portion of the scan. For each animal, $k_{2}{ }^{\prime}$ was initially estimated using the simplified reference tissue model (SRTM) (Lammertsma and Hume, 1996). The $B P_{N D}$ values were generated by subtracting 1 from the estimated volume of distribution ratios.

This article is protected by copyright. All rights reserved. 


\section{Histological analysis}

Seven months after viral injection, the minipigs were deeply anesthetized with $5 \mathrm{mg} / \mathrm{kg} \mathrm{S}$ -

Ketamine and $1.5 \mathrm{mg} / \mathrm{kg}$ Midazolam before they received an IC overdose injection of sodium pentobarbital (20 mL $400 \mathrm{mg} / \mathrm{mL}$, Exagon Vet, Richter pharma). Blood was flushed out using $5 \mathrm{~L}$ of $0.9 \%$ cold $\mathrm{NaCl}$ to permit collection of fresh striatal punches for analysis of metabolites for another study. Brain was removed and immediately sliced into $1 \mathrm{~cm}$ thick sections and the striatal hole punches were collected. The remaining sections were fixed in $4 \%$ paraformaldehyde in $0.1 \mathrm{M}$ phosphate buffer pH 7.4 for 4 days (Bjarkam et al. 2017b; Bjarkam et al. 2001). Next, brains were transferred to $10 \%$ sucrose solution for 2 days followed by a $30 \%$ sucrose solution for 7 days. Brains were then cut into $50 \mu \mathrm{m}$ thick coronal sections using a microtome (Microm HM450) - 12 series for each region - and stored in antifreeze solution (0.5 M phosphate buffer, $30 \%$ glycerol, $30 \%$ ethylene glycol) at $-20^{\circ} \mathrm{C}$ until further processing.

Brain sections were rinsed from antifreeze solution with Tris-buffered saline (TBS) (5 mM Tris, 15 $\mathrm{mM} \mathrm{NaCl}$ ) twice for $10 \mathrm{~min}$. For antigen retrieval, sections stained against tyrosine hydroxylase (TH) were placed into Tris / EDTA buffer $\mathrm{pH} 9.1$ for $30 \mathrm{~min}$ at $80^{\circ} \mathrm{C}$ and were rinsed again afterwards with buffer. Sections were then incubated in $3 \% \mathrm{H}_{2} \mathrm{O}_{2}$ and $10 \%$ Methanol in TBS for 30 min. Quenching solution was washed off with TBS for $10 \mathrm{~min}$ followed by two washes using $0.05 \%$ Triton X-100 in TBS (TBS-T). Sections were incubated for $30 \mathrm{~min}$ in TBS-T containing $5 \%$ of normal serum from the same animal species from which the secondary antibody was raised. Primary antibody solutions were applied overnight at room temperature (RT): 1\% BSA in TBS-T containing either rabbit anti-TH (AB1542, Millipore, USA) at 1:2,000; mouse anti-human $\alpha$-syn (610787, BD Biosciences, USA) at 1:30,000; rabbit anti-GFP (ab290, Abcam, UK) at 1:100,000. After 16- $20 \mathrm{~h}$, 
sections were rinsed three times with TBS-T for $10 \mathrm{~min}$ and incubated with the appropriate biotinylated secondary antibody (1:200, Vector Laboratories) in 1\% BSA in TBS-T for $1 \mathrm{~h}$. Sections were rinsed three times with TBS-T for $10 \mathrm{~min}$. The avidin-biotin-peroxidase complex solution (Vectastain Elite ABC kit, Vector Laboratories Inc, Burlingame, USA) was then applied for $1 \mathrm{~h}$. After rinsing sections again with TBS-T for 10 min then twice using TBS for $10 \mathrm{~min}$, staining was

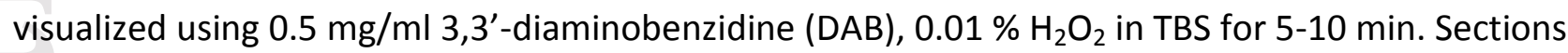
were washed with TBS and mounted on chromatin-gelatin coated glass slides, dehydrated in first $70 \%$, then $95 \%$ followed by $3 \times 100 \%$ Ethanol ( 2 min each) and cleared in $3 x$ xylene solution ( 5 min each). Immediately afterwards, sections were coverslipped using Depex (Sigma-Aldrich, Stockholm, Sweden). Images were taken on a Zeiss microscope (Axio Zoom.V16) for low power images or a Nikon microscope (eclipse 90i) for higher magnification images.

\section{Statistics}

Statistical tests were performed using Prism7 (GraphPad Software, California, USA). Values are presented as means \pm standard deviation (SD) if not otherwise specified. A kruskal-wallis one-way ANOVA was used to compare behavioural data. To compare mean regional $V_{T}$ and $B P_{N D}$ values, a repeated measures two-way ANOVA with animal groups and regions (repeated within-subject) as factors were performed with Tukey's multiple comparisons test. The statistical significance level was set at $P<0.05$.

This article is protected by copyright. All rights reserved. 


\section{Results}

\section{Response of motor behaviour}

From the EthoVision XT tracking analysis, the mean distance moved for the minipigs measured at baseline was $29.2 \pm 17.3$ meters. Four months following injection of AAV-GFP or AAV- $\alpha$-syn vectors, the mean distance moved for the GFP $(n=4)$ and $\alpha$-syn $(n=4)$ animals had decreased to $23.9 \pm 7.6$ and $28.9 \pm 11.2$ meters, respectively (Figure 2). A further minor decrease was observed after 6 month to $21.3 \pm 6.5$ meters ( $\alpha$-syn) and $17.7 \pm 0.8$ meters (GFP), although recordings were only obtained for 2 animals in each group at this time-point. Statistical analysis showed no significant difference between any of the groups $(P>0.05)$.

\section{$\left[{ }^{11} \mathrm{C}\right](\mathrm{R}) \mathrm{PK} 11195$ volume of distribution following rAAV transduction}

Regional estimates of $\left[{ }^{11} \mathrm{C}\right](\mathrm{R})$ PK11195 $V_{T}$ were obtained for the three groups of minipigs ( $\alpha$-syn $n=4$; GFP $n$ =2; Control $n=5$ ) using a population based input function and a 1-tissue compartment model with three free parameters $\left(K_{1}, k_{2}\right.$ and $\left.v B\right)$ which was preferred over a 2-tissue compartment model as it provided more robust parameter estimates. A comparison between findings from the left and the right sides of the brain within the groups revealed no differences larger than $2 \%$ in any of the regions sampled in either of the groups $(P>0.05)$. Therefore, left and right side regions of interest were merged and bilateral $V_{T}$ values were estimated again and compared between groups.

A repeated measures two-way ANOVA analysis found a significant effect of region $(F(7,56)=84.98, P<$ $0.0001)$, treatment $(F(2,8)=6.4, P=0.02)$, matching $(F(8,56)=43.54, P<0.0001)$ and interaction $(F(14$, 56) $=2.99, P=0.002$ ). Tukey's multiple comparisons test revealed that $\alpha$-syn subjects had significantly higher $V_{T}$ values than control animals in all brain regions sampled $(P<0.05)$ except the cerebellum (Figure

This article is protected by copyright. All rights reserved. 
3A). The largest effect of rAAV- $\alpha$-syn transduction on $\left[{ }^{11} \mathrm{C}\right](\mathrm{R}) \mathrm{PK} 11195$ binding was observed in regions closest to the nigral injection site (Figure 3A, B).

\section{Symmetric $\left[{ }^{11} \mathrm{C}\right] \mathrm{DTBZ}$ binding}

Analysis of the vesicular monoamine transporter 2 (VMAT2) $\left[{ }^{11}\right.$ C]DTBZ PET data, showed no effect of group or region on $B P_{N D}$ values between the $\alpha$-syn $(n=4)$, the GFP $(n=3)$ or the control group $(n=5)$ (Figure 4). Moreover, when comparing left and right striatal $B P_{N D}$ values within groups, no statistical differences $(P>$ 0.05) were observed.

\section{Histological examination of viral vector injections}

rAAV 2/5 containing a CBA promoter and either the human A53T $\alpha$-syn transgene, or GFP as a control, were unilaterally injected into minipig right SN. To visualize targeting and successful transduction of the rAAV, immunohistochemical stainings of matched selected sections of the minipig brain were performed to detect human- $\alpha$-syn (Figure $5 \mathrm{G}, \mathrm{H}, \mathrm{K}, \mathrm{L}$ ) and GFP (Figure $5 \mathrm{E}, \mathrm{F}, \mathrm{I}, \mathrm{J})$. Immunostaining for human $\alpha$-syn or GFP showed expression of the transgenes in the striatum (Figure $5 \mathrm{E}, \mathrm{G}$ ) as well as in the $\mathrm{SN}$, which confirmed the correct targeting of our injections into the right ventral midbrain. In both groups, backflow of the vector was seen around the injection tract into the midbrain / thalamic regions (Figure $5 \mathrm{~F}, \mathrm{H}, \mathrm{I}-\mathrm{J}$ ). Smaller cell bodies were transduced in the nigral region (Figure $5 \mathrm{~J}, \mathrm{~L}$ ) suggesting a high affinity of the rAAV5 for glial cells. In the striatum, bigger neurons, presumably medium spiny neurons (MSN) were labeled, especially visible in the GFP expressing animals (Figure $5 \mathrm{I}$ ) compared to the human $\alpha$-syn staining (Figure $5 \mathrm{~K}$ ) as GFP is a cytosolic protein while $\alpha$-syn appears mostly in terminals as puncta. TH staining in both striatum and midbrain sections showed no apparent fiber or cell loss, respectively, in the $\alpha$-syn group when compared to GFP expressing brains (Figure 5 A-D).

This article is protected by copyright. All rights reserved. 


\section{Discussion}

In this study we have delivered rAAV2/5 vectors expressing mutant $\alpha$-syn unilaterally into the $\mathrm{SN}$ of minipig brains and found a bilaterally increased $\left[{ }^{11} \mathrm{C}\right](\mathrm{R}) \mathrm{PK} 11195$ binding across all brain regions sampled 4 months after transduction, suggesting a widespread neuroinflammatory response which was highest around the injection site. As only smaller cells, possibly glial cells, rather than dopaminergic cells were transduced in the SNc, it was not surprising that the TH staining visually showed no dopaminergic cell or fiber loss in the SNc 7 months after transduction. In the striatum, MSN were transduced by the rAAV5 vector, which indicates that it was mainly taken up by either glial cells or by MSN axons in the ventral midbrain and then retrogradely transported to the striatum via the nigrostriatal pathway. From the TH staining, no dopaminergic terminal loss was observed in the striatum and similarly, results from $\left[{ }^{11} \mathrm{C}\right]$ DTBZ PET showed no changes in VMAT2 binding, a marker of dopamine terminal functional integrity, in the striatum of the $\alpha$ syn group compared to either the GFP or the control group 4 months after transduction. Furthermore, the distance moved by the animals in their cages was similar in the $\alpha$-syn and GFP group at 4 and 6 months after surgery, which corresponds with the presumable intact dopamine system in both groups.

Statistically significant increased $\left[{ }^{11} \mathrm{C}\right](\mathrm{R}) \mathrm{PK} 11195$ binding was detected in the striatum, thalamus, pons and the ventral midbrain (containing the SN) of the $\alpha$-syn inoculated minipigs, regions that are all affected by $\alpha$ syn pathology in PD patients (Braak et al. 2003). Damage to the neurons in the SN is considered the hallmark of PD leading to deafferentation of the striatum, which in turn sends strong projections to pallidum and thalamus (Braak et al. 2003; Gibb \& Lees 1991). As activated microglia release cytokines, such as TNF $\alpha$, they may well be a contributor to the ongoing degeneration of dopamine neurons in PD (Boka et al. 1994; Chung et al. 2009; McGuire et al. 2001). Indeed, increased $\left[{ }^{11} \mathrm{C}\right](\mathrm{R}) \mathrm{PK} 11195$ binding has been reported in the brainstem and cortical association areas of PD patients and it has been suggested that microglial activation may be an early event in the disease process (Gerhard et al. 2006; Ouchi et al. 2005).

This article is protected by copyright. All rights reserved. 
Glial pathology may be occurring before loss of nigral dopamine neurons in PD (Stokholm et al. 2017), and our minipigs show an early inflammatory response, which is most likely caused by the accumulation of aberrant $\alpha$-syn in glia and MSN neurons of the basal ganglia. Indeed, glial cells have been shown to scavenge and accumulate $\alpha$-syn in their cytoplasm in early PD, which normally leads to tissue destruction, but has also been shown to be beneficial in order to attenuate $\alpha$-syn pathology when preconditioned with cytokines (Halliday \& Stevens 2011; Koller et al. 2017; Lee et al. 2008; Lee et al. 2010). Furthermore, extracellular $\alpha$-syn is able to activate microglia through interaction with Toll-like receptors (Kim et al. 2013; Stefanova et al. 2011). However, $\left[{ }^{11} \mathrm{C}\right](\mathrm{R})$ PK11195 does not distinguish between TSPO expressed on microor astroglia and different activation states (i.e. pro- versus anti-inflammatory processes) and reactive astroglia have been shown to contribute to the TSPO PET signal, so further neurochemical and expression analysis would be needed to assess this (Lavisse et al. 2012). It is also possible that activated microglia vary in their protein expression profiles depending on their role in the various stages of neurodegeneration, which may complicate the association between increased TSPO binding and microglial activation (Gerhard 2016). Finally, the expression of TSPO on blood vessel endothelium may also be a confounding factor (Turkheimer et al. 2015).

Interestingly, the increased $\left[{ }^{11} \mathrm{C}\right](\mathrm{R}) \mathrm{PK} 11195$ binding in the rAAV- $\alpha$-syn animals was bilateral and global despite the unilateral injection into right SN. This could in part be explained by cross-innervation of the contralateral systems that may have helped the dissemination of the $\alpha$-syn protein to the contralateral hemisphere. Indeed, crossed nigrostriatal connections have been observed in non-human primates as indicated by horseradish peroxidase labeled neurons in SN contralateral to the striatal injection (Francois et al. 1984). As backflow of the viral vector along the needle tract was seen to the dorsal midbrain and thalamus, it is also possible that $\alpha$-syn was transported along thalamic projections. Moreover, following

This article is protected by copyright. All rights reserved. 
needle insertion with local tissue damage and inflammation, the rAAV vectors might have induced further immune response to an already sensitive system.

Histological analysis revealed expression of cytosolic GFP in striatal MSN suggesting a vector transduction of MSN axon fibers in the $\mathrm{SN}$ and a retrograde transport of the vector. In contrast to the cytosolic expression of GFP, expression of $\alpha$-syn showed a more punctated structure and therefore most likely a more synaptic translocation of this protein in the MSN neurons. In the SNc, smaller cell bodies were stained which might indicate a possible preference of the vector to transduce glial cells over dopaminergic neurons. Previously, widespread transduction of the brain has been observed with the rAAV5 vector injected into thalamus and putamen of non-human primates (Samaranch et al. 2017). Samaranch et al. 2017 reported a primary transduction of neurons (both dopaminergic nigral neurons and striatal MSN) and astrocytes as well as a robust antero- and retrograde transport of AAV5 through nigrostriatal and thalamic projections (Samaranch et al. 2017). A study done in neonatal minipigs using intra-striatal injection also showed that the rAAV5-GFP vector predominantly transduced neurons in striatum, neocortex, thalamus and SN, with some GFP-positive cells showing a glial profile (Kornum et al. 2010). Interestingly, they reported a difference in rAAV5-GFP transduction between 2 day-old and 7 week-old piglets, where the older pigs showed lower spread and transduction of neuronal cells further away from the injection site (Kornum et al. 2010). As the minipig brain is fully myelinated at 6 months of age (Fang et al. 2005) and as we used Göttingen minipigs aged at least 11 months at the time of surgery, the age could have affected the vector transduction and possibly also the neuronal and glial protein expression profiles for receptors necessary to bind and internalize the vector. Furthermore, the study by Kornum et al. (2010) used intra-striatal injection whereas we used intra-nigral injection, which may have altered the transduction efficiency.

This article is protected by copyright. All rights reserved. 
Similar studies in marmosets showed that $90-95 \%$ of TH-positive neurons in the SN were transduced with the recombinant AAV vector (Kirik et al. 2003). This clearly demonstrates interspecies differences, as delivery of rAAV5 vectors in the rat brain also resulted in effective transduction of neurons in $\mathrm{SN}$, striatum, hippocampus and cortex and widespread transgene expression (Davidson et al. 2000; Kornum et al. 2010; Ulusoy et al. 2010). Alternatively, since both marmoset and rat brains are very small compared to minipig brain, it is possible that more than one injection may be necessary to produce sufficient infection in a large brain and measurable dopaminergic deficits. Different vectors should also be tested to improve the transduction of dopaminergic nigral neurons of the minipig in future studies to achieve a more effective transduction. This is supported by previous studies revealing different transduction patterns dependent on virus vector serotype, capsid, promoter sequence, titer, target region and animal species (Davidson et al. 2000; Gerits et al. 2015).

Only 2 out of 4 GPF animals were available for the $\left[{ }^{11} \mathrm{C}\right](\mathrm{R})$ PK11195 PET quantification (1 animal sustained an immediate infection from the surgery and 1 animal had a failed PET scan). One of the PET scanned GFP animals had a $\left[{ }^{11} \mathrm{C}\right](\mathrm{R}) \mathrm{PK} 11195$ binding comparable to the $\alpha$-syn minipigs, which suggests that there might have been some inflammation caused by the surgery itself, especially in view of the opening of the dura mater. Indeed, introducing a vector carrying a non-mammal exogenous protein like GFP might trigger a widespread immune reaction. Furthermore, GFP at high concentrations has previously been reported to be associated with toxicity and inflammatory response (Landeck et al. 2017; Ulusoy et al. 2009). The higher $\left[{ }^{11} \mathrm{C}\right](\mathrm{R}) \mathrm{PK} 11195$ signal from this animal might be a direct effect of the protein itself. The other GFP animal had binding corresponding to the higher range of the control group so more GFP controls or empty vector controls will be needed in a future study to assess the variability and mean binding in this group.

This article is protected by copyright. All rights reserved. 
Second generation TSPO radioligands have been developed with a higher signal-to-noise ratio than $\left[{ }^{11} \mathrm{C}\right](\mathrm{R}) \mathrm{PK} 11195$ but their binding affinity in humans is influenced by TSPO gene polymorphisms complicating quantification (Owen et al. 2012). We aimed at making our study comparable to existing human studies and for this reason selected $\left[{ }^{11} \mathrm{C}\right](\mathrm{R}) \mathrm{PK} 11195$ for which abundant data are available (Bartels \& Leenders 2007; Gerhard et al. 2006; Parbo et al. 2017). Unfortunately, microglia and TSPO sites are ubiquitously distributed throughout the brain and may become activated by any local pathology, disconnection of the region from damaged areas, and as a part of the aging process (Banati 2002; Hinz \& Boellaard 2015; Kumar et al. 2012; Turkheimer et al. 2007). Lower TSPO binding in the cerebellum compared to other grey matter regions is used as a justification for its use as a tissue reference in PET imaging studies (Doble et al. 1987). An increase in cerebellum binding has been reported in some pathology cases (Gerhard et al. 2006), and as we did not know a priori the extent of viral dissemination and its possible effect on cerebellum, we used the alternative approach of a population based metabolitecorrected input function to obtain the binding estimate (manuscript in preparation) (Shiozaki et al. 2000; Tsuchida et al. 1999).

In conclusion, we found that the unilateral nigral injection of viral vectors overexpressing $\alpha$-syn induced a significantly increased bilateral inflammatory response in sub- and cortical regions detectable with the TSPO ligand $\left[{ }^{11} \mathrm{C}\right](\mathrm{R}) \mathrm{PK} 11195$ PET. However, no changes were detected in the function of dopaminergic neurons assessed in vivo with $\left[{ }^{11} \mathrm{C}\right]$ DTBZ PET of the VMAT2, at post mortem with TH staining or behaviorally through motor assessment. Our study may therefore demonstrate glial activation as an early response to neuronal accumulation of $\alpha$-syn in the absence of VMAT2 or TH changes. It will be of interest to test different viral vectors in future studies to find a serotype that better targets dopaminergic neurons located in the SN of the minipig for the purpose of developing a large animal model of PD in which putative treatments and promising PET biomarkers can be tested.

This article is protected by copyright. All rights reserved. 


\section{References}

Alstrup, A. K. O., Munk, O. L., Landau, A. M., \& Lillethorup, T. P. (2018). PET radioligand injection for pig neuroimaging. Scandinavian Journal of Laboratory Animal Science, in press, 44(2).

Banati, R. B. (2002). Visualising microglial activation in vivo. Glia, 40(2), 206-217. doi:10.1002/glia.10144

Barkholt, P., Sanchez-Guajardo, V., Kirik, D., \& Romero-Ramos, M. (2012). Long-term polarization of microglia upon alpha-synuclein overexpression in nonhuman primates. Neuroscience, 208, 85-96. doi:10.1016/j.neuroscience.2012.02.004

Bartels, A. L., \& Leenders, K. L. (2007). Neuroinflammation in the pathophysiology of Parkinson's disease: evidence from animal models to human in vivo studies with [11C]-PK11195 PET. Mov Disord, 22(13), 1852-1856. doi:10.1002/mds.21552

Bjarkam, C. R., Glud, A. N., Orlowski, D., Sorensen, J. C. H., \& Palomero-Gallagher, N. (2017a). The telencephalon of the Gottingen minipig, cytoarchitecture and cortical surface anatomy. Brain Struct Funct, 222(5), 2093-2114. doi:10.1007/s00429-016-1327-5

Bjarkam, C. R., Orlowski, D., Tvilling, L., Bech, J., Glud, A. N., \& Sorensen, J. H. (2017b). Exposure of the Pig CNS for Histological Analysis: A Manual for Decapitation, Skull Opening, and Brain Removal. J Vis Exp, 122, 55511. Retrieved from doi:10.3791/55511

Bjarkam, C. R., Pedersen, M., \& Sorensen, J. C. (2001). New strategies for embedding, orientation and sectioning of small brain specimens enable direct correlation to MR-images, brain atlases, or use of unbiased stereology. J Neurosci Methods, 108(2), 153-159.

Boka, G., Anglade, P., Wallach, D., Javoy-Agid, F., Agid, Y., \& Hirsch, E. C. (1994). Immunocytochemical analysis of tumor necrosis factor and its receptors in Parkinson's disease. Neurosci Lett, 172(1-2), 151154.

Bonsack, F. t., Alleyne, C. H., Jr., \& Sukumari-Ramesh, S. (2016). Augmented expression of TSPO after intracerebral hemorrhage: a role in inflammation? J Neuroinflammation, 13(1), 151. doi:10.1186/s12974-016-0619-2

Braak, H., Del Tredici, K., Rub, U., de Vos, R. A., Jansen Steur, E. N., \& Braak, E. (2003). Staging of brain pathology related to sporadic Parkinson's disease. Neurobiol Aging, 24(2), 197-211.

Cagnin, A., Brooks, D. J., Kennedy, A. M., Gunn, R. N., Myers, R., Turkheimer, F. E., Jones, T., \& Banati, R. B. (2001). In-vivo measurement of activated microglia in dementia. Lancet, 358(9280), 461-467. doi:10.1016/S0140-6736(01)05625-2

Chung, C. Y., Koprich, J. B., Siddiqi, H., \& Isacson, O. (2009). Dynamic changes in presynaptic and axonal transport proteins combined with striatal neuroinflammation precede dopaminergic neuronal loss in a rat model of AAV alpha-synucleinopathy. J Neurosci, 29(11), 3365-3373. doi:10.1523/JNEUROSCI.5427-

This article is protected by copyright. All rights reserved. 
Cumming, P., Danielsen, E. H., Vafaee, M., Falborg, L., Steffensen, E., Sorensen, J. C., Gillings, N., Bender, D., Marthi, K., Andersen, F., Munk, O., Smith, D., Moller, A., \& Gjedde, A. (2001). Normalization of markers for dopamine innervation in striatum of MPTP-lesioned miniature pigs with intrastriatal grafts. Acta Neurol Scand, 103(5), 309-315.

Cumming, P., Pedersen, M. D., Minuzzi, L., Mezzomo, K., Danielsen, E. H., Iversen, P., Aagaard, D., Keiding, S., Munk, O. L., \& Finsen, B. (2006). Distribution of PK11195 binding sites in porcine brain studied by autoradiography in vitro and by positron emission tomography. Synapse, 59(7), 418-426. doi:10.1002/syn.20257

Davidson, B. L., Stein, C. S., Heth, J. A., Martins, I., Kotin, R. M., Derksen, T. A., Zabner, J., Ghodsi, A., \& Chiorini, J. A. (2000). Recombinant adeno-associated virus type 2, 4, and 5 vectors: transduction of variant cell types and regions in the mammalian central nervous system. Proc Natl Acad Sci U S A, 97(7), 3428-3432. doi:10.1073/pnas.050581197

Doble, A., Malgouris, C., Daniel, M., Daniel, N., Imbault, F., Basbaum, A., Uzan, A., Gueremy, C., \& Le Fur, G. (1987). Labelling of peripheral-type benzodiazepine binding sites in human brain with [3H]PK 11195: anatomical and subcellular distribution. Brain Res Bull, 18(1), 49-61.

Ettrup, K. S., Glud, A. N., Orlowski, D., Fitting, L. M., Meier, K., Soerensen, J. C., Bjarkam, C. R., \& Alstrup, A. K. (2011). Basic surgical techniques in the Gottingen minipig: intubation, bladder catheterization, femoral vessel catheterization, and transcardial perfusion. J Vis Exp, 52, 2652. doi:10.3791/2652

Fang, M., Li, J., Gong, X., Antonio, G., Lee, F., Kwong, W. H., Wai, S. M., \& Yew, D. T. (2005). Myelination of the pig's brain: a correlated MRI and histological study. Neurosignals, 14(3), 102-108. doi:10.1159/000086292

Francois, C., Percheron, G., \& Yelnik, J. (1984). Localization of nigrostriatal, nigrothalamic and nigrotectal neurons in ventricular coordinates in macaques. Neuroscience, 13(1), 61-76.

Gerhard, A. (2016). TSPO imaging in parkinsonian disorders. Clin Transl Imaging, 4, 183-190. doi:10.1007/s40336-016-0171-1

Gerhard, A., Pavese, N., Hotton, G., Turkheimer, F., Es, M., Hammers, A., Eggert, K., Oertel, W., Banati, R. B., \& Brooks, D. J. (2006). In vivo imaging of microglial activation with [11C](R)-PK11195 PET in idiopathic Parkinson's disease. Neurobiol Dis, 21(2), 404-412. doi:10.1016/j.nbd.2005.08.002

Gerits, A., Vancraeyenest, P., Vreysen, S., Laramee, M. E., Michiels, A., Gijsbers, R., Van den Haute, C., Moons, L., Debyser, Z., Baekelandt, V., Arckens, L., \& Vanduffel, W. (2015). Serotype-dependent transduction efficiencies of recombinant adeno-associated viral vectors in monkey neocortex. Neurophotonics, 2(3), 031209. doi:10.1117/1.NPh.2.3.031209

Gibb, W. R., \& Lees, A. J. (1991). Anatomy, pigmentation, ventral and dorsal subpopulations of the substantia nigra, and differential cell death in Parkinson's disease. J Neurol Neurosurg Psychiatry, 54(5),

This article is protected by copyright. All rights reserved. 
388-396.

Glud, A. N., Bech, J., Tvilling, L., Zaer, H., Orlowski, D., Fitting, L. M., Ziedler, D., Geneser, M., Sangill, R., Alstrup, A. K. O., Bjarkam, C. R., \& Sorensen, J. C. H. (2017). A fiducial skull marker for precise MRIbased stereotaxic surgery in large animal models. J Neurosci Methods, 285, 45-48. doi:10.1016/j.jneumeth.2017.04.017

Glud, A. N., Hedegaard, C., Nielsen, M. S., Soorensen, J. C., Bendixen, C., Jensen, P. H., Mogensen, P. H., Larsen, K., \& Bjarkam, C. R. (2011). Direct MRI-guided stereotaxic viral mediated gene transfer of alphasynuclein in the Gottingen minipig CNS. Acta Neurobiol Exp (Wars), 71(4), 508-518.

Grimm, D., Kern, A., Rittner, K., \& Kleinschmidt, J. A. (1998). Novel tools for production and purification of recombinant adenoassociated virus vectors. Hum Gene Ther, 9(18), 2745-2760. doi:10.1089/hum.1998.9.18-2745

Gunn, R. N., Gunn, S. R., \& Cunningham, V. J. (2001). Positron emission tomography compartmental models. J Cereb Blood Flow Metab, 21(6), 635-652. doi:10.1097/00004647-200106000-00002

Guo, Q., Colasanti, A., Owen, D. R., Onega, M., Kamalakaran, A., Bennacef, I., Matthews, P. M., Rabiner, E. A., Turkheimer, F. E., \& Gunn, R. N. (2013). Quantification of the specific translocator protein signal of 18F-PBR111 in healthy humans: a genetic polymorphism effect on in vivo binding. J Nucl Med, 54(11), 1915-1923. doi:10.2967/jnumed.113.121020

Halliday, G. M., \& Stevens, C. H. (2011). Glia: initiators and progressors of pathology in Parkinson's disease. Mov Disord, 26(1), 6-17. doi:10.1002/mds.23455

Hinz, R., \& Boellaard, R. (2015). Challenges of quantification of TSPO in the human brain. Clinical and Translational Imaging, 3(6), 403-416. doi:10.1007/s40336-015-0138-7

Kim, C., Ho, D. H., Suk, J. E., You, S., Michael, S., Kang, J., Joong Lee, S., Masliah, E., Hwang, D., Lee, H. J., \& Lee, S. J. (2013). Neuron-released oligomeric alpha-synuclein is an endogenous agonist of TLR2 for paracrine activation of microglia. Nat Commun, 4, 1562. doi:10.1038/ncomms2534

Kirik, D., Annett, L. E., Burger, C., Muzyczka, N., Mandel, R. J., \& Bjorklund, A. (2003). Nigrostriatal alphasynucleinopathy induced by viral vector-mediated overexpression of human alpha-synuclein: a new primate model of Parkinson's disease. Proc Natl Acad Sci U S A, 100(5), 2884-2889. doi:10.1073/pnas.0536383100

Kirik, D., Rosenblad, C., Burger, C., Lundberg, C., Johansen, T. E., Muzyczka, N., Mandel, R. J., \& Bjorklund, A. (2002). Parkinson-like neurodegeneration induced by targeted overexpression of alpha-synuclein in the nigrostriatal system. J Neurosci, 22(7), 2780-2791. doi:20026246

Koller, E. J., Brooks, M. M., Golde, T. E., Giasson, B. I., \& Chakrabarty, P. (2017). Inflammatory preconditioning restricts the seeded induction of alpha-synuclein pathology in wild type mice. Mol Neurodegener, 12(1), 1. doi:10.1186/s13024-016-0142-z

This article is protected by copyright. All rights reserved. 
Kornum, B. R., Stott, S. R., Mattsson, B., Wisman, L., Ettrup, A., Hermening, S., Knudsen, G. M., \& Kirik, D. (2010). Adeno-associated viral vector serotypes 1 and 5 targeted to the neonatal rat and pig striatum induce widespread transgene expression in the forebrain. Exp Neurol, 222(1), 70-85. doi:10.1016/j.expneurol.2009.12.009

Kumar, A., Muzik, O., Shandal, V., Chugani, D., Chakraborty, P., \& Chugani, H. T. (2012). Evaluation of agerelated changes in translocator protein (TSPO) in human brain using (11)C-[R]-PK11195 PET. J Neuroinflammation, 9, 232. doi:10.1186/1742-2094-9-232

Landeck, N., Buck, K., \& Kirik, D. (2017). Toxic effects of human and rodent variants of alpha-synuclein in vivo. Eur J Neurosci, 45(4), 536-547. doi:10.1111/ejn.13493

Lavisse, S., Guillermier, M., Herard, A. S., Petit, F., Delahaye, M., Van Camp, N., Ben Haim, L., Lebon, V., Remy, P., Dolle, F., Delzescaux, T., Bonvento, G., Hantraye, P., \& Escartin, C. (2012). Reactive astrocytes overexpress TSPO and are detected by TSPO positron emission tomography imaging. J Neurosci, 32(32), 10809-10818. doi:10.1523/JNEUROSCI.1487-12.2012

Lee, H. J., Suk, J. E., Bae, E. J., \& Lee, S. J. (2008). Clearance and deposition of extracellular alpha-synuclein aggregates in microglia. Biochem Biophys Res Commun, 372(3), 423-428. doi:10.1016/j.bbrc.2008.05.045

Lee, H. J., Suk, J. E., Patrick, C., Bae, E. J., Cho, J. H., Rho, S., Hwang, D., Masliah, E., \& Lee, S. J. (2010). Direct transfer of alpha-synuclein from neuron to astroglia causes inflammatory responses in synucleinopathies. J Biol Chem, 285(12), 9262-9272. doi:10.1074/jbc.M109.081125

Lind, N. M., Moustgaard, A., Jelsing, J., Vajta, G., Cumming, P., \& Hansen, A. K. (2007). The use of pigs in neuroscience: modeling brain disorders. Neurosci Biobehav Rev, 31(5), 728-751. doi:10.1016/j.neubiorev.2007.02.003

Logan, J., Fowler, J. S., Volkow, N. D., Wang, G. J., Ding, Y. S., \& Alexoff, D. L. (1996). Distribution volume ratios without blood sampling from graphical analysis of PET data. J Cereb Blood Flow Metab, 16(5), 834-840. doi:10.1097/00004647-199609000-00008

Maingay, M., Romero-Ramos, M., \& Kirik, D. (2005). Viral vector mediated overexpression of human alphasynuclein in the nigrostriatal dopaminergic neurons: a new model for Parkinson's disease. CNS Spectr, 10(3), 235-244.

McGeer, P. L., Itagaki, S., Boyes, B. E., \& McGeer, E. G. (1988). Reactive microglia are positive for HLA-DR in the substantia nigra of Parkinson's and Alzheimer's disease brains. Neurology, 38(8), 1285-1291.

McGeer, P. L., Schwab, C., Parent, A., \& Doudet, D. (2003). Presence of reactive microglia in monkey substantia nigra years after 1-methyl-4-phenyl-1,2,3,6-tetrahydropyridine administration. Ann Neurol, 54(5), 599-604. doi:10.1002/ana.10728

McGuire, S. O., Ling, Z. D., Lipton, J. W., Sortwell, C. E., Collier, T. J., \& Carvey, P. M. (2001). Tumor necrosis factor alpha is toxic to embryonic mesencephalic dopamine neurons. Exp Neurol, 169(2), 219-230.

This article is protected by copyright. All rights reserved. 
doi:10.1006/exnr.2001.7688

Orr, C. F., Rowe, D. B., \& Halliday, G. M. (2002). An inflammatory review of Parkinson's disease. Prog Neurobiol, 68(5), 325-340.

Ouchi, Y., Yoshikawa, E., Sekine, Y., Futatsubashi, M., Kanno, T., Ogusu, T., \& Torizuka, T. (2005). Microglial activation and dopamine terminal loss in early Parkinson's disease. Ann Neurol, 57(2), 168-175. doi:10.1002/ana.20338

Owen, D. R., Yeo, A. J., Gunn, R. N., Song, K., Wadsworth, G., Lewis, A., Rhodes, C., Pulford, D. J., Bennacef, I., Parker, C. A., StJean, P. L., Cardon, L. R., Mooser, V. E., Matthews, P. M., Rabiner, E. A., \& Rubio, J. P. (2012). An 18-kDa translocator protein (TSPO) polymorphism explains differences in binding affinity of the PET radioligand PBR28. J Cereb Blood Flow Metab, 32(1), 1-5. doi:10.1038/jcbfm.2011.147

Papadopoulos, V., Baraldi, M., Guilarte, T. R., Knudsen, T. B., Lacapere, J. J., Lindemann, P., Norenberg, M. D., Nutt, D., Weizman, A., Zhang, M. R., \& Gavish, M. (2006). Translocator protein (18kDa): new nomenclature for the peripheral-type benzodiazepine receptor based on its structure and molecular function. Trends Pharmacol Sci, 27(8), 402-409. doi:10.1016/j.tips.2006.06.005

Parbo, P., Ismail, R., Hansen, K. V., Amidi, A., Marup, F. H., Gottrup, H., Braendgaard, H., Eriksson, B. O., Eskildsen, S. F., Lund, T. E., Tietze, A., Edison, P., Pavese, N., Stokholm, M. G., Borghammer, P., Hinz, R., Aanerud, J., \& Brooks, D. J. (2017). Brain inflammation accompanies amyloid in the majority of mild cognitive impairment cases due to Alzheimer's disease. Brain, 140(7), 2002-2011. doi:10.1093/brain/awx120

Phan, J. A., Stokholm, K., Zareba-Paslawska, J., Jakobsen, S., Vang, K., Gjedde, A., Landau, A. M., \& RomeroRamos, M. (2017). Early synaptic dysfunction induced by alpha-synuclein in a rat model of Parkinson's disease. Sci Rep, 7(1), 6363. doi:10.1038/s41598-017-06724-9

Samaranch, L., Blits, B., San Sebastian, W., Hadaczek, P., Bringas, J., Sudhakar, V., Macayan, M., Pivirotto, P. J., Petry, H., \& Bankiewicz, K. S. (2017). MR-guided parenchymal delivery of adeno-associated viral vector serotype 5 in non-human primate brain. Gene Ther, 24(4), 253-261. doi:10.1038/gt.2017.14

Sanchez-Guajardo, V., Febbraro, F., Kirik, D., \& Romero-Ramos, M. (2010). Microglia acquire distinct activation profiles depending on the degree of alpha-synuclein neuropathology in a rAAV based model of Parkinson's disease. PLoS One, 5(1), e8784. doi:10.1371/journal.pone.0008784

Shiozaki, T., Sadato, N., Senda, M., Ishii, K., Tsuchida, T., Yonekura, Y., Fukuda, H., \& Konishi, J. (2000). Noninvasive estimation of FDG input function for quantification of cerebral metabolic rate of glucose: optimization and multicenter evaluation. J Nucl Med, 41(10), 1612-1618.

Stefanova, N., Fellner, L., Reindl, M., Masliah, E., Poewe, W., \& Wenning, G. K. (2011). Toll-like receptor 4 promotes alpha-synuclein clearance and survival of nigral dopaminergic neurons. Am J Pathol, 179(2), 954-963. doi:10.1016/j.ajpath.2011.04.013

Stokholm, M. G., Iranzo, A., Ostergaard, K., Serradell, M., Otto, M., Svendsen, K. B., Garrido, A., Vilas, D.,

This article is protected by copyright. All rights reserved. 
Borghammer, P., Santamaria, J., Moller, A., Gaig, C., Brooks, D. J., Tolosa, E., \& Pavese, N. (2017). Assessment of neuroinflammation in patients with idiopathic rapid-eye-movement sleep behaviour disorder: a case-control study. Lancet Neurol. Retrieved from doi:10.1016/S1474-4422(17)30173-4

Tsuchida, T., Sadato, N., Yonekura, Y., Nakamura, S., Takahashi, N., Sugimoto, K., Waki, A., Yamamoto, K., Hayashi, N., \& Ishii, Y. (1999). Noninvasive measurement of cerebral metabolic rate of glucose using standardized input function. J Nucl Med, 40(9), 1441-1445.

Turkheimer, F. E., Edison, P., Pavese, N., Roncaroli, F., Anderson, A. N., Hammers, A., Gerhard, A., Hinz, R., Tai, Y. F., \& Brooks, D. J. (2007). Reference and target region modeling of [11C]-(R)-PK11195 brain studies. J Nucl Med, 48(1), 158-167.

Turkheimer, F. E., Rizzo, G., Bloomfield, P. S., Howes, O., Zanotti-Fregonara, P., Bertoldo, A., \& Veronese, M. (2015). The methodology of TSPO imaging with positron emission tomography. Biochem Soc Trans, 43(4), 586-592. doi:10.1042/BST20150058

Ulusoy, A., Decressac, M., Kirik, D., \& Bjorklund, A. (2010). Viral vector-mediated overexpression of alphasynuclein as a progressive model of Parkinson's disease. Prog Brain Res, 184, 89-111. doi:10.1016/S0079-6123(10)84005-1

Ulusoy, A., Sahin, G., Bjorklund, T., Aebischer, P., \& Kirik, D. (2009). Dose optimization for long-term rAAVmediated RNA interference in the nigrostriatal projection neurons. Mol Ther, 17(9), 1574-1584. doi:10.1038/mt.2009.142

van der Putten, H., Wiederhold, K. H., Probst, A., Barbieri, S., Mistl, C., Danner, S., Kauffmann, S., Hofele, K., Spooren, W. P., Ruegg, M. A., Lin, S., Caroni, P., Sommer, B., Tolnay, M., \& Bilbe, G. (2000). Neuropathology in mice expressing human alpha-synuclein. J Neurosci, 20(16), 6021-6029.

Venneti, S., Lopresti, B. J., \& Wiley, C. A. (2006). The peripheral benzodiazepine receptor (Translocator protein $18 \mathrm{kDa}$ ) in microglia: from pathology to imaging. Prog Neurobiol, 80(6), 308-322. doi:10.1016/j.pneurobio.2006.10.002

Watanabe, H., Andersen, F., Simonsen, C. Z., Evans, S. M., Gjedde, A., Cumming, P., \& DaNe, X. S. G. (2001). MR-based statistical atlas of the Gottingen minipig brain. Neuroimage, 14(5), 1089-1096. doi:10.1006/nimg.2001.0910

Zolotukhin, S., Byrne, B. J., Mason, E., Zolotukhin, I., Potter, M., Chesnut, K., Summerford, C., Samulski, R. J., \& Muzyczka, N. (1999). Recombinant adeno-associated virus purification using novel methods improves infectious titer and yield. Gene Ther, 6(6), 973-985. doi:10.1038/sj.gt.3300938

This article is protected by copyright. All rights reserved. 
Figure legends

Figure 1. No difference in parent fraction between animal groups. Unmetabolized parent fractions from the 3 groups of animals measured in arterial plasma. The plotted bars are mean \pm standard deviation and the line is the fitted metabolite data using a sigmoid model.

Figure 2. Distance moved in the minipigs by video tracking. Minipigs were filmed at baseline, including naïve controls, and were again recorded 4 and 6 months after either GFP-or $\alpha$-syn injection. The bars indicate the mean and standard deviation.

Figure 3. Volume of distribution of activated microglia determined by in vivo $\left[{ }^{11} \mathrm{C}\right](\mathrm{R}) \mathrm{PK} 11195$. (A) $\left[{ }^{11} \mathrm{C}\right](\mathrm{R}) \mathrm{PK} 11195$ volume of distribution (mean \pm standard deviation) in different brain regions between the naïve control group $(n=5)$, GFP $(n=2)$ and $\alpha$-syn animals $(n=4)$. Significant $p$-values are represented as $* p<0.05, * * * p<0.001$ and $* * * * p<0.0001$. Abbreviations for the volumes of interest: $\mathrm{VM}=$ Ventral Midbrain, $\mathrm{STR}=$ Striatum, $\mathrm{THA}=$ Thalamus, FC = Frontal Cortex, $\mathrm{TC}=$ Temporal Cortex, Cer $=$ Cerebellum, $\mathrm{WhBr}=$ Whole Brain. (B) Pixel-wise parametric $\mathrm{V}_{\mathrm{T}}$ maps. An average of the rAAV-GFP and control animals (Top row) and an average of the rAAV- $\alpha$-syn animals (Bottom row) are displayed in coronal, transverse and sagittal views.

Figure 4. VMAT2 binding levels determined by in vivo $\left[{ }^{11} \mathrm{C}\right] \mathrm{DTBZ} . B P_{N D}$ values found four months after the $\mathrm{rAAV}$ injections and for naïve controls are presented with bars representing mean and standard deviation. Results are shown for 5 control scans, 3 GFP animals and $4 \alpha$-syn animals in right and left striatum.

Figure 5. Immunohistochemical staining of TH and the transgenes 7 months post-surgery. THpositive cells in striatum and SN of GFP animal (A, B) and A53T $\alpha$-syn animal (C, D). Low magnification photos of the GFP-positive staining in striatum (E), and midbrain (F), and of the human $\alpha$-syn expression in striatum (G), midbrain (H). High magnification images show GFPpositive cells in striatum (I) and SNc (J). Also $\alpha$-syn-positive cells were observed in the striatum (K) and SNc (L). The vector transfected glial cells and neurons in the ventral (SN) and dorsal (thalamo) midbrain. The transgenes were anterogradely transported from SNc $(\mathbf{F} / \mathbf{J}$ and $\mathbf{H} / \mathbf{L})$ to striatum $(\mathbf{E} / \mathbf{I}$ and G/K) via the medial forebrain bundle (not shown). Scale bar A-H: $1 \mathrm{~mm}$. Scale bar I-L: $50 \mu \mathrm{m}$.

This article is protected by copyright. All rights reserved. 
$\alpha$-syn $=\alpha$-Synuclein, GFP $=$ Green Fluorescent Protein, SN = substantia nigra, SNc $=$ substantia nigra pars compacta, $\mathrm{TH}=$ Tyrosine hydroxylase.
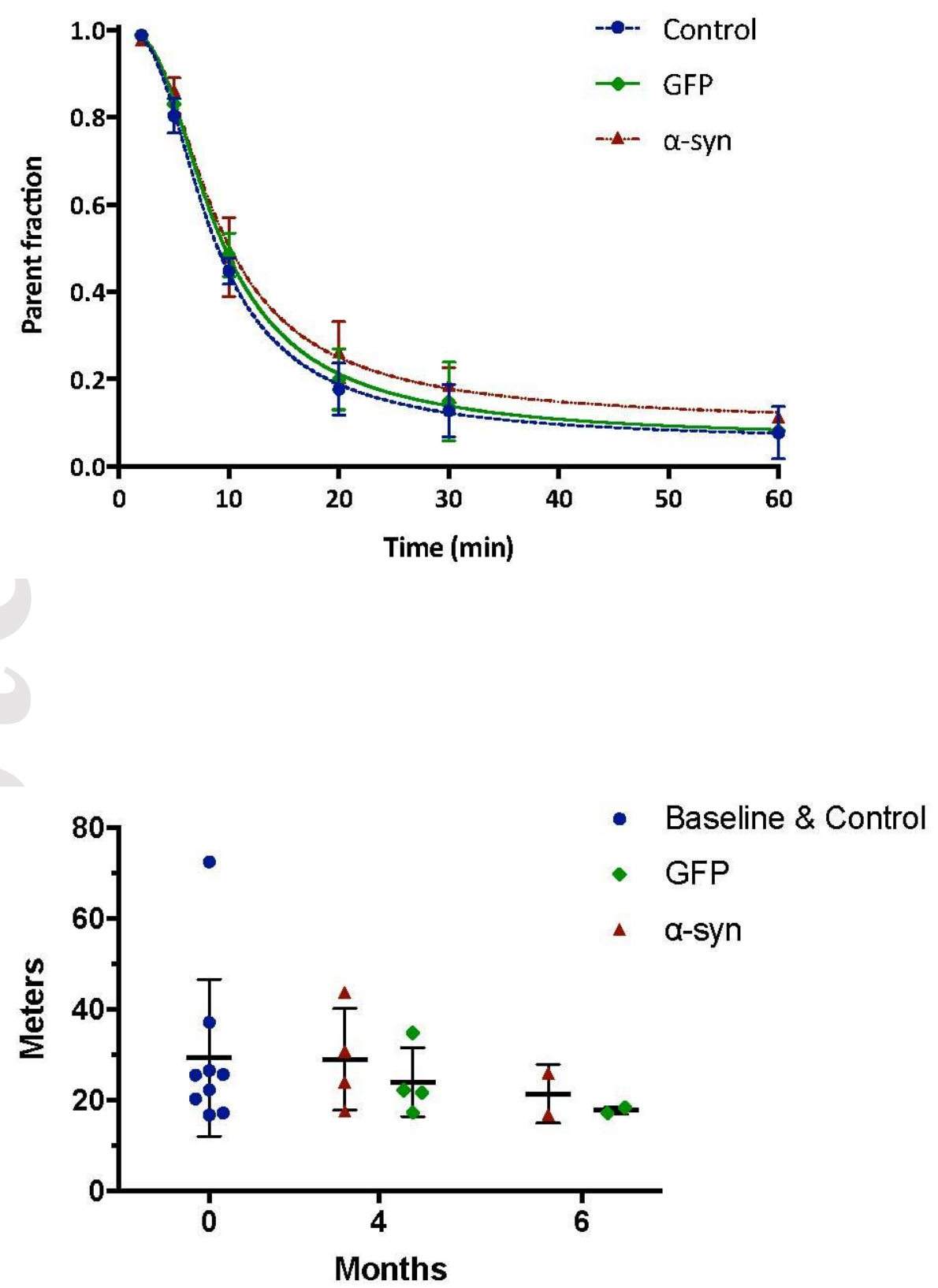

This article is protected by copyright. All rights reserved. 
A

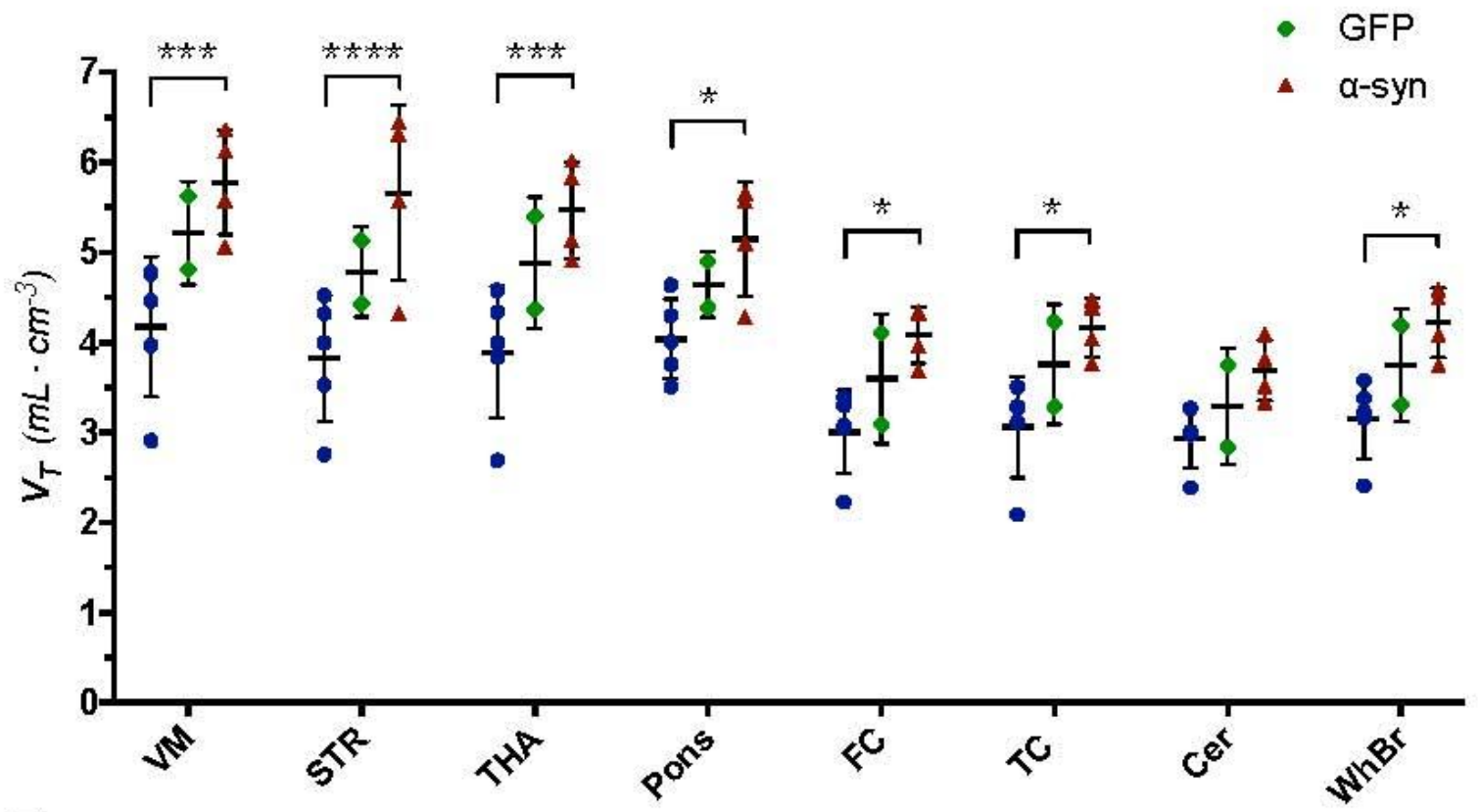

B
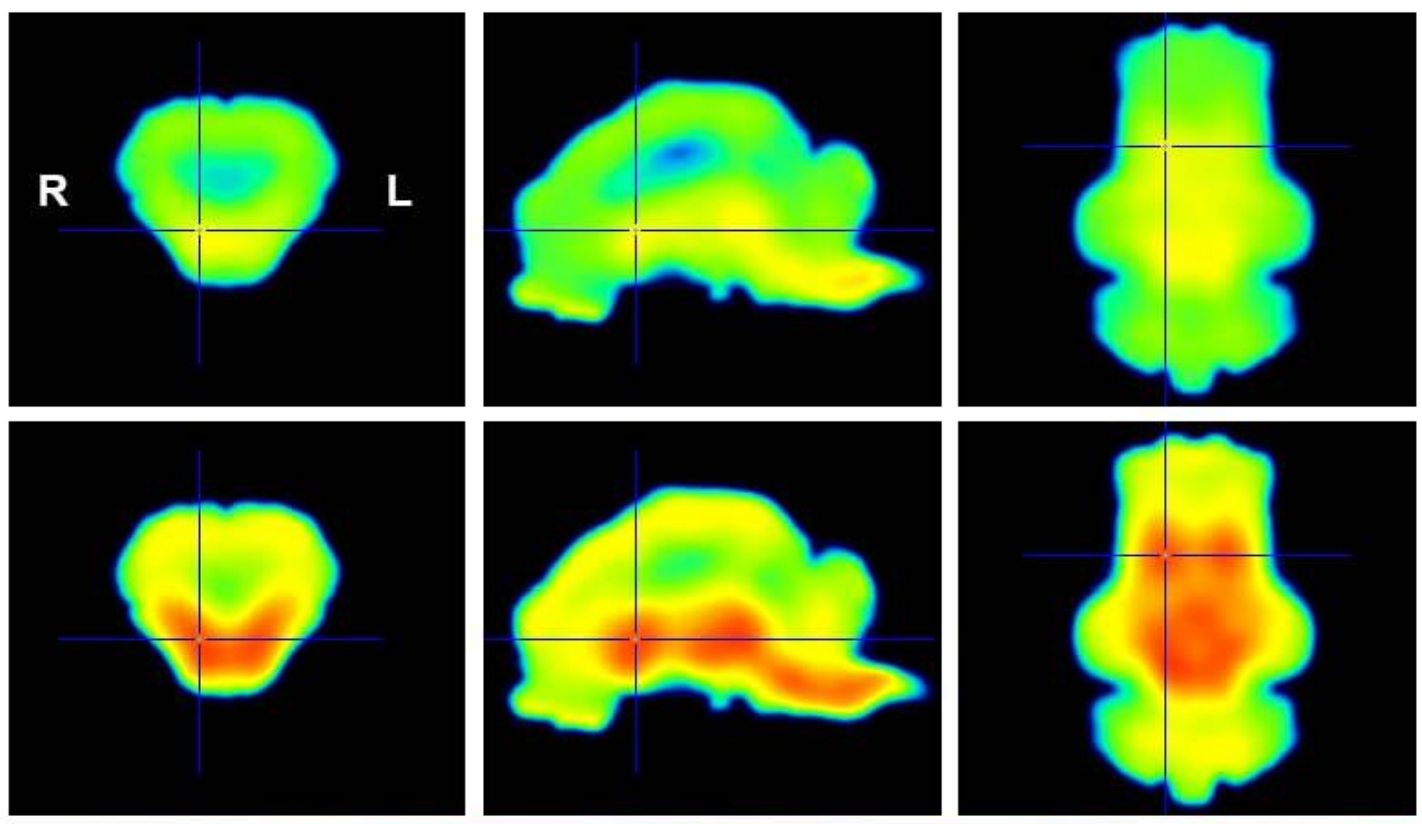

0.0

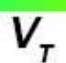

6.5

This article is protected by copyright. All rights reserved. 


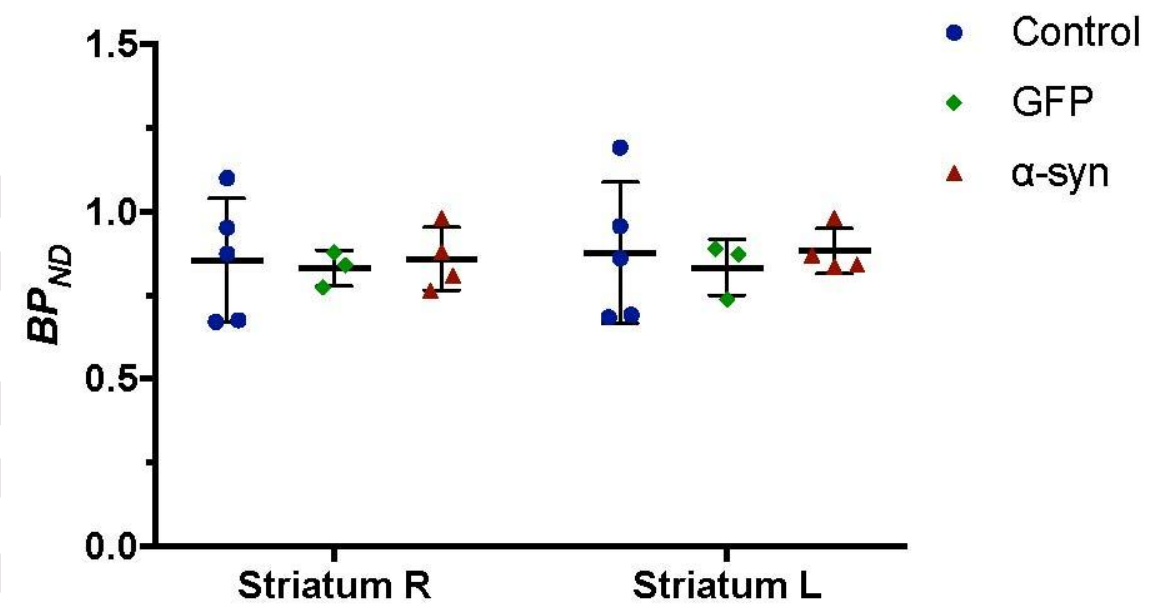

This article is protected by copyright. All rights reserved. 


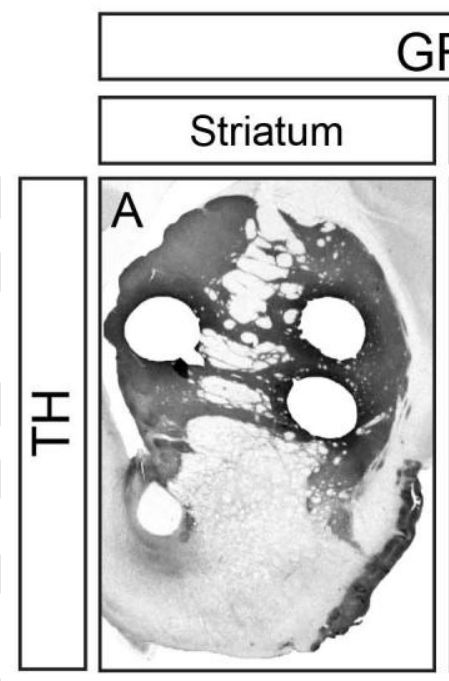

\section{GFP}
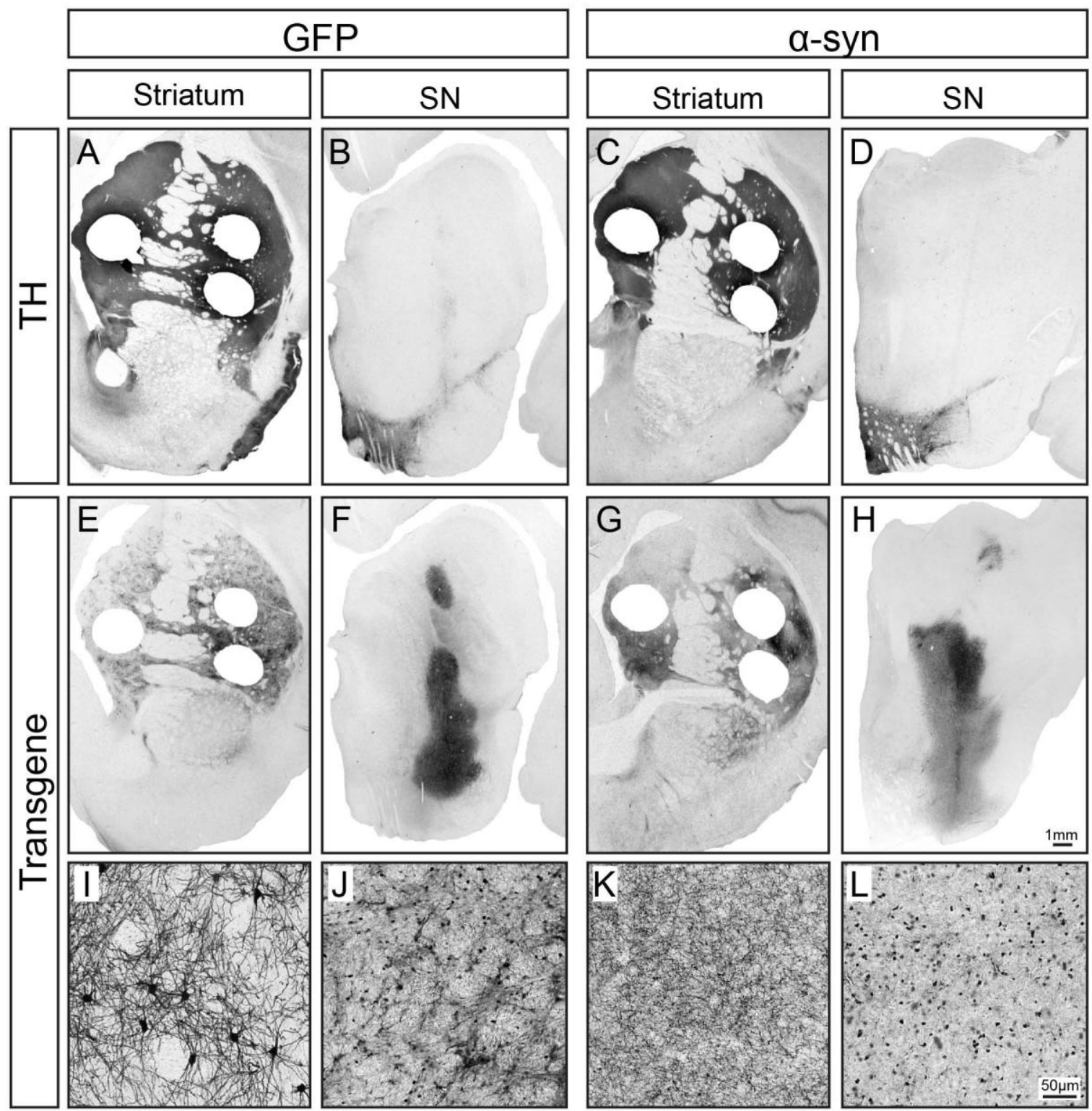

This article is protected by copyright. All rights reserved. 